\title{
Presentació. \\ Emocions, violència de gènere, formació, ocupació
}

Aquest volum miscel.lani presenta un tema innovador en la sociologia contemporània: les emocions, les subjectivitats, la intencionalitat. Malauradament, les emocions que deriven en un comportament violent han tingut com a conseqüència la mort de moltes dones i d'alguns homes a mans de llurs marits o mullers. Tot i que el fenomen no és nou (a l'època franquista aquests assassinats s'anomenaven crims passionals i tenien l'eximent de la passió com a inductora de l'acció delictiva), un cop els divorcis són pauta comuna entre moltes parelles que no s'avenen, sembla augmentar el nombre de denúncies i de delictes mortals contra les dones. La llei contra la violència de gènere és el complement de la llei de divorci en la protecció de la convivència. La família, el divorci, l'educació dels fills, la generació del capital social en el sistema educatiu són altres temes presents en el volum. S'ha dit que l'educació i la inversió en educació com a capital social representen un factor de reconducció i control de les conductes violentes. El sistema educatiu acull la població escolar immigrant i conforma aules multiètniques i pluriculturals. La convivència harmònica du freqüentment moltes parelles a adoptar fills. Els aspectes psicosocials d'aquesta decisió s'analitzen també en aquest volum. Un tercer bloc d'articles se centra en la base econòmica de molts fenòmens socials. Un dels clàssics més moderns de la sociologia, Georg Simmel, va establir les bases de la sociologia econòmica. Les classes socials continuen sent una categoria fonamental per analitzar les societats actuals. El petit empresariat conforma la classe social mitjana o petita burgesia, cabdal en la seva ampliació entre els dos extrems de l'escala social per evitar la polarització de la societat i el conflicte social per les desigualtats socials de classe. El tercer sector contribueix a reforçar aquesta tendència. 